\title{
Spécificités des techniques viti-vinicoles
}

\section{Claude Royer}

\section{OpenEdition}

Journals

Édition électronique

URL : https://journals.openedition.org/tc/1024

DOI : $10.4000 /$ tc. 1024

ISSN : 1952-420X

\section{Éditeur}

Éditions de l'EHESS

\section{Édition imprimée}

Date de publication : 1 septembre 1983

ISSN : 0248-6016

\section{Référence électronique}

Claude Royer, "Spécificités des techniques viti-vinicoles », Techniques \& Culture [En ligne], 2 | 1983, mis en ligne le 26 janvier 2006, consulté le 29 septembre 2022. URL : http://journals.openedition.org/tc/ 1024 ; DOI : https://doi.org/10.4000/tc.1024

Ce document a été généré automatiquement le 29 septembre 2022.

Tous droits réservés 


\title{
Spécificités des techniques viti- vinicoles
}

\author{
Claude Royer
}

